\title{
Hepatic Steatosis in Iranian Patients with Chronic Hepatitis C
}

\author{
Mohammad Minakari ${ }^{a}$ Farzaneh Khadem Sameni ${ }^{\mathrm{b}}$ \\ Hamid Mohaghegh Shalmani ${ }^{b}$ Mahsa Molaee ${ }^{b}$ Mohammad-Reza Zali ${ }^{b}$ \\ aDepartments of Gastroenterology and Hepatology, Isfahan University of Medical Sciences, Isfahan, and \\ ${ }^{b}$ Research Center of Gastroenterology and Liver Disease, Shaheed Beheshti University, Tehran, Iran
}

\section{Key Words}

Chronic hepatitis $C \cdot$ Steatosis $\cdot$ Hepatitis $C$ virus, genotype $\cdot$ Viral load

\begin{abstract}
Objectives: To evaluate the frequency and severity of fibrosis, and also the association of various viral and host factors of steatosis in Iranian patients with hepatitis $\mathrm{C}(\mathrm{CHC})$. Subjects and Methods: Eighty treatment-naïve $\mathrm{CHC}$ patients, age $37.6 \pm 11.77$ years, were studied. Percutaneous liver biopsy was performed for all patients. Based on pathology reports, patients were divided into two groups: with and without significant steatosis. Hepatitis C virus RNA (HCV-RNA), various viral and host factors, and biochemical findings and genotyping of HCV were compared in the two groups. $\boldsymbol{R e}$ sults: Of the 80 patients, 42 (52.5\%) had pathologic evidence of significant steatosis. The mean serum level of cholesterol, triglyceride, glucose, and $\gamma$-glutamyl transpeptidase as well as the mean body mass index, viral load, stage of fibrosis and frequency of genotype 3 were significantly higher in the patients with than those without steatosis $(p<0.05)$. In multivariate analysis, only genotype 3 and viral load had significant association with steatosis. In patients with genotype 3 infection, the mean viral load in those with and without steatosis was 1,623,357 \pm 833,543.46 and 821,262.1 \pm 924,480 copies/ml, respectively, and the difference was statistically significant $(p=0.009)$. The mean viral load in patients with
\end{abstract}

genotype 1 infection was not significantly different between the two groups. The mean stage of fibrosis was higher in the group that had significant steatosis $(p<0.05)$. Conclusion: Steatosis is a common finding in Iranian patients with $\mathrm{CHC}$. Infection with HCV genotype 3 and high viral load in these patients are associated with significant steatosis.

Copyright $\odot 2008$ S. Karger AG, Basel

\section{Introduction}

Chronic hepatitis $\mathrm{C}(\mathrm{CHC})$ is thought to affect more than 170 million people worldwide, and it has been shown that steatosis occurs in approximately $50 \%$ of patients with CHC [1]. Steatosis also occurs more than twice as frequently in patients with $\mathrm{CHC}$ than in the general population [2]. Both viral and host metabolic factors have been reported to contribute to the genesis of hepatic steatosis in patients with $\mathrm{CHC}$. Most steatosis is mild, with the more severe cases usually occurring in genotype 3 virus infection [3]. Given that both $\mathrm{CHC}$ and nonalcoholic fatty liver disease (NAFLD) are relatively common diseases, it is not surprising that both may occur concomitantly. In fact, the presence of coexistent nonalcoholic steatohepatitis, the more aggressive form of NAFLD, is found in $5-10 \%$ of biopsy specimens from patients with $\mathrm{CHC}[4,5]$.

\section{KARGER}

Fax +41 613061234

E-Mail karger@karger.ch

www.karger.com
(C) 2008 S. Karger AG, Basel

$1011-7571 / 08 / 0172-0126 \$ 24.50 / 0$

Accessible online at:

www.karger.com/mpp
Mohammad Minakari

Ass. Prof. of Gastroenterology and Hepatology, Department of Internal Medicine Al-Zahra Hospital, Shohadaye Sofeh Street

Isfahan (Iran)

Tel. +98 311 2369250, Fax +983116687898,E-Mail mmminakari@yahoo.com 
Two distinct forms of hepatocellular steatosis can be seen in patients with chronic hepatitis $\mathrm{C}$ virus (HCV) infection. Classical metabolic risk factors of hepatocellular steatosis account for the vast majority of cases of steatosis in patients infected by nongenotype $3 \mathrm{HCV}$ strains [6]. In contrast, in patients infected by HCV genotype 3, steatosis is generally induced by the virus itself through a direct cytopathic effect, the mechanisms of which remain debated. Mixed forms of steatosis can also be seen in HCV genotype 3-infected patients with metabolic risk factors [3]. The presence of steatosis seems to have a significant impact on the natural history and progression of fibrosis in patients with $\mathrm{CHC}[7,8]$. The efficacy of antiviral therapy has been shown to be diminished in the setting of coexistent hepatic steatosis and nongenotype $3 \mathrm{CHC}$ as reported by several investigators [9-12]. Unfortunately, there is no study regarding the prevalence and risk factors of steatosis in Iranian patients with CHC. Hence, the objective of this study was to evaluate the frequency and severity of fibrosis and also the association of various viral and host factors of steatosis in Iranian patients with $\mathrm{CHC}$.

\section{Subjects and Methods}

In this cross-sectional analytical study, 93 consecutive patients with CHC who were referred to Taleghani Hospital, Tehran from May 2004 to May 2006 for liver biopsy were included with nonprobability convenient sampling. The study was approved by the Ethics Committee, Research Centre of Gastroenterology and Liver Diseases. Informed consent was obtained from all patients.

$\mathrm{CHC}$ was defined according to positive serum HCV-Ab and HCV-RNA for at least 6 months and elevated levels of serum aminotransferases (AST, ALT). Exclusion criteria were: patients who had any serological evidence of infection with other viruses (HBV, HDV, HIV), history of regular alcohol consumption and use of any medications known to cause NAFLD, patients with clinical or laboratory evidence of decompensated liver disease, and patients who had received any kind of treatment for $\mathrm{CHC}$. Thirteen such patients ( 9 male and 4 female) were excluded and hence 80 patients were enrolled in the study. Mean age was $37.67 \pm 11.77$, range 17-61 years; 64 males and 16 females.

Percutaneous liver biopsy was performed for all the patients. Two hepatopathologists evaluated biopsy samples. Based on the pathology findings, the patients were divided into two groups: group A without significant steatosis (steatosis in $<33 \%$ of hepatocytes) and group B with significant steatosis (steatosis in $>33 \%$ of hepatocytes), according to the classification of Brunt and Tiniakos [13] and Brunt [14]. Age, gender, body mass index (BMI), serum cholesterol, triglyceride, fasting blood sugar, AST, ALT, alkaline phosphatase, $\gamma$-glutamyl transpeptidase (GGT), HCV genotype, HCV-RNA viral load and liver fibrotic stage were determined and compared in the two groups. Biochemical tests and
HCV-RNA (viral load) were performed by autoanalyzer (Selecta, Germany) and Cobas Amplicore monitor version 2 (Roche Molecular Systems, Branchburgh, N.J., USA), respectively.

BMI was calculated by the formula: weight $(\mathrm{kg}) /$ height ${ }^{2}\left(\mathrm{~m}^{2}\right)$. Stage of fibrosis was determined according to Metavir Scoring System (0-4) by a pathologist. Genotyping of HCV was determined by genotype-specific primers [15]. Statistical analysis was performed using SPSS version 13 with $\chi^{2}$ test, independent-sample $t$ test and logistic regression.

\section{Results}

Of the 80 patients, 42 (52.5\%, 33 males and 9 females) had pathologic evidence of significant steatosis. Of the 42 with significant steatosis, $33(78.57 \%)$ had moderate steatosis (in 33-66\% of hepatocytes) and 9 (21.42\%) had severe steatosis (in $>66 \%$ of hepatocytes). The remaining 38 patients (31 males and 7 females) did not have significant steatosis (0-33\% hepatocytes). Characteristics of patients with $\mathrm{CHC}$ are shown in table 1 . There was no significant difference between the mean age of patients with steatosis $(37.05 \pm 11.21$ years) and without steatosis $(38.37 \pm 12.48$ years). The BMI of the group with steatosis $(23.48 \pm 5.43)$ was significantly higher than the nonsteatosis group (21.21 $\pm 4.04 \mathrm{~kg} / \mathrm{m}^{2} ; \mathrm{p}=0.036$ ). Mean viral load in patients with and without steatosis was $1,256,452.38 \pm 823,342.81$ and $821,352.63 \pm 870,330.57$ copies $/ \mathrm{ml}$, respectively $(\mathrm{p}=$ $0.024)$. As shown in table 1 , the mean serum level of cholesterol, triglyceride, fasting glucose, and GGT was significantly higher among patients with steatosis. There was no significant difference between mean serum AST, ALT and alkaline phosphatase in the two groups. Mean score of fibrosis was $2.17 \pm 0.91$ and $1.63 \pm 1.02$ in patients with and without steatosis, respectively $(\mathrm{p}=0.015)$.

Of 38 patients without steatosis, 27 (71.05\%) had genotype $1,7(18.42 \%)$ had genotype 3 , and $4(10.52 \%)$ had other genotypes. This latter group contained 3 patients with genotype 2 and 1 patient of undetermined genotype. Of 42 patients with steatosis, 16 (38.09\%) had genotype 1 , 24 (57.14\%) had genotype 3, and $2(0.0476 \%)$ had genotype 2 . The frequency of patients with genotype 1 in the group without steatosis was significantly higher than in the group with steatosis $(\mathrm{p}=0.003)$, while the frequency of patients with genotype 3 in the group with steatosis was significantly higher than in the group without steatosis $(\mathrm{p}=0.0000)$. The morphology of steatosis was macrovesicular in all patients. Microvesicular steatosis was also present in 13 of 42 patients (30.95\%), but the degree of microvesicular steatosis was less than $33 \%$ of steatotic hepatocytes in all of them. 
Table 1. Characteristics of $\mathrm{CHC}$ patients with or without significant steatosis (mean $\pm \mathrm{SD}$ )

\begin{tabular}{lccc}
\hline & With steatosis $(\mathrm{n}=38)$ & Without steatosis $(\mathrm{n}=42)$ & $\mathrm{p}$ value \\
\hline Age, years & $37.05 \pm 11.21$ & $38.37 \pm 12.48$ & 0.619 \\
BMI & $23.48 \pm 5.43$ & $21.21 \pm 4.04$ & 0.036 \\
Cholesterol, mg/dl & $217.69 \pm 30.24$ & $200.32 \pm 24.82$ & 0.007 \\
Triglyceride, mg/dl & $215.45 \pm 58.27$ & $188.13 \pm 31.56$ & 0.010 \\
Viral load, copies/ml & $1,256,452.38 \pm 823,342.81$ & $821,352.63 \pm 870,330.57$ & 0.024 \\
FBS, mg/dl & $105.95 \pm 23.21$ & $95 \pm 21.52$ & 0.032 \\
AST, IU/l & $72.48 \pm 33.69$ & $67.58 \pm 31.86$ & 0.507 \\
ALT, IU/l & $84.29 \pm 36.55$ & $81.71 \pm 34.76$ & 0.748 \\
ALKP, IU/l & $185.86 \pm 58.53$ & $184.26 \pm 54.80$ & 0.901 \\
GGT, IU/l & $36.14 \pm 18.57$ & $28.29 \pm 11.99$ & 0.026 \\
Fibrosis, Metavir Scoring System & $2.17 \pm 0.91$ & $1.63 \pm 1.02$ & 0.015 \\
\hline
\end{tabular}

FBS = Fasting blood sugar; AST = aminotransferase; ALT = alanine transaminase; ALKP = alkaline phosphatase.

In multivariate analysis of the effect of viral factors (genotype and viral load) and metabolic host factors (cholesterol, triglyceride, fasting blood glucose, BMI) and serum GGT, only viral load ( $\mathrm{p}=0.04, \mathrm{R}=0.14$ ) and genotype 3 were the significant variables in the model. For all other variables, $\mathrm{p}$ ranged from 0.06 (cholesterol) to 0.67 (triglyceride).

The mean viral load in patients with genotype 3 infection with steatosis $(1,623,357 \pm 833,543.46$ copies $/ \mathrm{ml})$ was significantly higher than the mean viral load in patients with genotype 3 infection without steatosis $(821,262.1 \pm 924,480$ copies $/ \mathrm{ml}, \mathrm{p}=0.009)$. The mean viral load in patients with genotype 1 infection with steatosis $(1,128,500 \pm 809,417.77$ copies $/ \mathrm{ml})$ was not significantly different from the mean viral load in patients with genotype 1 infection without steatosis $(928,857.1 \pm$ $749,548.18$ copies $/ \mathrm{ml}, \mathrm{p}=0.565)$. Because of their very low frequency, patients with genotype 2 were not analyzed separately.

\section{Discussion}

$\mathrm{CHC}$ and steatosis are common entities that can have interactive synergistic effect on the liver. Steatosis is frequently observed in $\mathrm{CHC}$ and seems to have a significant impact on the natural history of the disease with respect to development of fibrosis and reduction of virologic response to current therapy [16]. The frequency of steatosis obtained in this study (52.5\%) is similar to the previously reported value of $50 \%$, in which most of the patients had moderate steatosis [3].
The sex distribution and mean age were not significantly different between the patients with and without steatosis, similar to findings of several other studies [3, $17,18]$.

However, the mean level of serum cholesterol, triglyceride, GGT, fasting blood sugar and BMI were significantly higher in patients with steatosis. The mean BMI was significantly higher in patients with than without steatosis as previously reported $[3,6-8]$.

Obesity, hyperlipidemia and hyperglycemia are indicators of insulin resistance and have strong association with NAFLD with or without chronic viral hepatitis [1724]. There is some evidence that an elevated serum GGT level is a sensitive marker for insulin resistance [24]. Hence, increases in serum GGT level may be amongst the earliest biochemical findings in patients with NAFLD [25] as in this study where serum levels of GTT were significantly higher in patients who had stenosis.

The relative frequencies of various genotypes of $\mathrm{HCV}$ in our study are similar to previous studies in Iran [26], in which genotypes 1 and 3 have been shown to be the most common genotypes. In multivariate analysis, only genotype 3 virus was associated with high HCV-RNA level that leads to significant steatosis as previously reported by other investigators $[27,28]$. Such a high association accelerates the progression of liver injury [27]. Other investigators have also shown that in genotype 1, steatosis was associated with host factors such as leptin, BMI, percentage of body fat, and visceral obesity [29] and also daily alcohol intake and histological activity grade (but not viral load) [28]. These findings suggest that steatosis is a cytopathic lesion induced by HCV genotype 3 , 
whereas HCV genotype 1 is not steatogenic per se [28]. Rubbia-Brandt et al. [30] have shown that the morphology of steatosis was macrovesicular in patients with either genotype 1 or genotype 3 infection. They concluded that the hepatocyte steatosis seen in $\mathrm{CHC}$ may be directly caused by HCV, thus representing the morphological expression of a cytopathic effect of HCV genotype 3 and a derangement of the hepatocyte lipid metabolism caused by a viral protein, although host protein(s) may play a role as additional co-factors. Hence, we speculate that the morphology of steatosis of genotype 3 of our study is also of the macrovesicular type. The direct responsibility of $\mathrm{HCV}$ in the pathogenesis of steatosis is shown by: (a) the association with HCV genotype 3 infection, suggesting that some viral sequences are involved in the intracellular accumulation of lipids, (b) the correlation between severity of steatosis and HCV replication levels, and (c) association between response to treatment and disappearance of steatosis [31].

In this study, the mean stage of fibrosis was significantly higher in the group with than without steatosis. Because this was a cross-sectional study, a direct causeand-effect relationship between steatosis and fibrosis in our patients could not be established. However, the negative impact of hepatic steatosis in $\mathrm{CHC}$ on response to current antiviral therapies has been shown in several studies [10-13]. If this is true, liver biopsy could have an additional important role in the management of patients with CHC. Currently, most physicians consider liver biopsy an optional choice in the management of patients with genotypes 2 or 3 infected with $\mathrm{CHC}$ because these patients have a more favorable response to antiviral therapies than those with genotype $1[9,10]$. However, it seems prudent to perform a liver biopsy before treatment in patients at risk for the presence of steatosis (patients with genotype 3 who have a high level of HCV-RNA) because these patients may be more difficult to treat and need a longer duration of treatment.

\section{Conclusion}

Steatosis is a common finding in Iranian patients with $\mathrm{CHC}$. Steatosis is associated with high viral load in patients who are infected with HCV genotype 3 , while in $\mathrm{HCV}$ genotype 1 infection, steatosis is associated with some host factors such as obesity, hyperglycemia, hyperlipidemia and high serum GGT.

\section{Acknowledgment}

This study is supported by a research grant from the Research Center of Gastroenterology and Liver Disease, Shaheed Beheshti University, Tehran, Iran.

\section{References}

1 Harrison SA: Steatosis and chronic hepatitis $\mathrm{C}$ infection: mechanisms and significance. Clin Gastroenterol Hepatol 2005;3:S92S96.

2 Lonardo A, Adinolfi LE, Loria P, Carulli N, Ruggiero G, Day CP: Steatosis and hepatitis C: mechanisms and significance for hepatic and extrahepatic disease. Gastroenterology 2004; 126:586-597.

3 Castera L, Chouteau P, Hezode C, Zafrani ES, Dhumeaux D, Pawlotsky JM: Hepatitis C virus-induced hepatocellular steatosis. Am J Gastroenterol 2005; 100:711-715.

-4 Brunt EM, Ramrakhiani S, Cordes BG, Neuschwander-Tetri BA, Janney CG, Bacon BR, Di Bisceglie AM: Concurrence of histologic features of steatohepatitis with other forms of chronic liver disease. Mod Pathol 2003; 16:49-56

5 Ong JP, Younossi ZM, Speer C, Olano A, Gramlich T, Boparai N: Chronic hepatitis C and superimposed nonalcoholic fatty liver disease. Liver 2001;21:266-271.
6 Gordon A, McLean CA, Pedersen JS, Bailey MJ, Roberts SK: Hepatic steatosis in chronic hepatitis B and C: predictors, distribution and effect on fibrosis. J Hepatol 2005;43:3844.

7 Fartoux L, Chazouilleres O, Wendum D, Poupon R, Serfaty L: Impact of steatosis on progression of fibrosis in patients with mild hepatitis C. Hepatology 2005;41:82-87.

$\checkmark 8$ Muzzi A, Leandro G, Rubbia-Brandt L, James R, Keiser O, Malinverni R, Dufour JF, Helbling B, Hadengue A, Gonvers JJ, Mullhaupt B, Cerny A, Mondelli MU, Negro F; Swiss Hepatitis C Cohort Study: Insulin resistance is associated with liver fibrosis in non-diabetic chronic hepatitis $\mathrm{C}$ patients. J Hepatol 2005;42:41-46.

-9 Poynard T, Ratziu V, McHutchison J, Manns M, Goodman Z, Zeuzem S, Younossi Z, Albrecht J: Effect of treatment with peginterferon or interferon alfa-2b and ribavirin on steatosis in patients infected with hepatitis C. Hepatology 2003;38:75-85.
10 Thomopoulos KC, Theocharis GJ, Tsamantas AC, Siagris D, Dimitropoulou D, Gogos CA, Labropoulou-Karatza C: Liver steatosis is an independent risk factor for treatment failure in patients with chronic hepatitis C. Eur J Gastroenterol Hepatol 2005; 17:149153.

11 Patton HM, Patel K, Behling C, Bylund D, Blatt LM, Vallee M, Heaton S, Conrad A, Pockros PJ, McHutchison JG: The impact of steatosis on disease progression and early and sustained treatment response in chronic hepatitis C patients. J Hepatol 2004;40:484490.

12 Harrison SA, Brunt EM, Oliver DA Neuschwander-Tetri BA, Di Bisceglie AM, Bacon BR: Effect of significant histologic steatosis or steatohepatitis on response to antiviral therapy in patients with chronic hepatitis C. Clin Gastroenterol Hepatol 2005;3: 604-609.

13 Brunt EM, Tiniakos DG: Pathology of steatohepatitis. Best Pract Res Clin Gastroenterol 2002;16:691-707. 
14 Brunt EM: Nonalcoholic steatohepatitis: definition and pathology. Semin Liver Dis 2001;21:3-16.

15 Ohno O, Mizokami M, Wu RR, Saleh MG, Ohba K, Orito E, Mukaide M, Williams R, Lau JY: New hepatitis C virus (HCV) genotyping system that allows for identification of HCV genotypes 1a, 1b, 2a, 2b, 3a, 3b, 4, 5a and 6a. J Clin Microbiol 1997;35:201-207.

16 Patel K, Zekry A, McHutchison JG: Steatosis and chronic hepatitis $\mathrm{C}$ virus infection: mechanisms and significance. Clin Liver Dis 2005;9:399-410.

-17 Fartoux L, Poujol-Robert A, Guéchot J, Wendum D, Poupon R, Serfaty L: Insulin resistance is a cause of steatosis and fibrosis progression in chronic hepatitis C. Gut 2005;54 1003-1008.

18 Liu CJ, Jeng YM, Chen PJ, Lai MY, Yang HC Huang WL, Kao JH, Chen DS: Influence of metabolic syndrome, viral genotype and antiviral therapy on superimposed fatty liver disease in chronic hepatitis C. Antivir Ther 2005;10:405-415.

19 Sheth SB, Gordon FD, Chopra S: Non alcoholic steatohepatitis. Ann Intern Med 1997; 126:137.

20 Sanyal AJ, Campbell-Sargent C, Mirshahi F, Rizzo WB, Contos MJ, Sterling RK, Luketic VA, Shiffman ML, Clore JN: Nonalcoholic steatohepatitis: association of insulin resistance and mitochondrial abnormalities. Gastroenterology 2001;120:1183-1192.
21 Chitturi S, Abeygunasekera S, Farrell GC, Holmes-Walker J, Hui JM, Fung C, Karim R, Lin R, Samarasinghe D, Liddle C, Weltman $\mathrm{M}$, George J: NASH and insulin resistance: insulin hypersecretion and specific association with the insulin resistance syndrome. Hepatology 2002;35:373-379.

22 Willner IR, Waters B, Patil SR, Reuben A, Morelli J, Riely CA: Ninety patients with nonalcoholic steatohepatitis: insulin resistance, familial tendency, and severity of disease. Am J Gastroenterol 2001;96:29572961.

23 Pagano G, Pacini G, Musso G, Gambino R, Mecca F, Depetris N, Cassader M, David E, Cavallo-Perin P, Rizzetto M: Nonalcoholic steatohepatitis, insulin resistance, and metabolic syndrome: further evidence for an etiologic association. Hepatology 2002;35:367372 .

24 Marchesini G, Brizi M, Morselli-Labate AM, Bianchi G, Bugianesi E, McCullough AJ, Forlani G, Melchionda N: Association of nonalcoholic fatty liver disease with insulin resistance. Am J Med 1999;107:450-455.

25 Ratziu V, Giral P, Charlotte F, Bruckert E, Thibault V, Theodorou I, Khalil L, Turpin G, Opolon P, Poynard T: Liver fibrosis in overweight patients. Gastroenterology 2000;118: 1117-1123.
26 Hosseini-Moghaddam SM, Keyvani H, Kasiri H, Kazemeyni SM, Basiri A, Aghel N, Alavian SM: Distribution of hepatitis C virus genotypes among hemodialysis patients in Tehran: a multicenter study. J Med Virol 2006;78:569-573.

27 Adinolfi LE, Utili R, Andreana A, Tripodi MF, Marracino M, Gambardella M, Giordano M, Ruggiero G: Serum HCV RNA levels correlate with histological liver damage and concur with steatosis in progression of chronic hepatitis C. Dig Dis Sci 2001;46: 1677-1683.

28 Hezode C, Roudot-Thoraval F, Zafrani ES, Dhumeaux D, Pawlotsky JM: Different mechanisms of steatosis in hepatitis $\mathrm{C}$ virus genotypes 1 and 3 infections. J Viral Hepat 2004;11:455-458.

29 Romero-Gomez M, Castellano-Megias VM, Grande L, Irles JA, Cruz M, Nogales MC, Alcon JC, Robles A: Serum leptin levels correlate with hepatic steatosis in chronic hepatitis C. Am J Gastroenterol 2003;98: 1135-1141.

-30 Rubbia-Brandt L, Quadri R, Abid K, Giostra E, Male PJ, Mentha G, Spahr, Zarski JP, Borisch B, Hadengue A, Negro F: Hepatocyte steatosis is a cytopathic effect of hepatitis C virus genotype 3. J Hepatol 2000;33: 106-115.

-31 Negro F: Mechanisms and significance of liver steatosis in hepatitis $\mathrm{C}$ virus infection. World J Gastroenterol 2006;12:6756-6765. 